\title{
Faktor Penghambat Implementasi Proyek Transportasi Masal berbasis Rel di Surabaya dengan Skema Kerjasama Pemerintah dengan Badan Usaha
}

\author{
Erfandi Zen Variamen ${ }^{1, ~}$, Mohammad Arif Rohman", \\ Departemen Teknik Sipil, Institut Teknologi Sepuluh Nopember, Surabaya ${ }^{1}$ \\ Koresponden*,Email: Zen.19031@mhs.its.ac.id*
}

\begin{tabular}{lc}
\hline & Info Artikel \\
\hline Diajukan & 05 Agustus 2021 \\
Diperbaiki & 23 November 2021 \\
Disetujui & 23 November 2021
\end{tabular}

Keywords:PPPs, tram surabaya, relative importance index, proyek infrastruktur, mass transportation
Kata kunci: KPBU, tram surabaya, relative importance index, proyek infrastruktur, transportasi masal

\begin{abstract}
Public Private Partnership (PPPs) is one of the financing solutions in fulfilling infrastructure development for better public services. The rapid rate of population growth in the city of Surabaya is a challenge in developing transportation infrastructure. The alternative strategy is to revive rail-based mass transportation or called Tram. The purpose of this study is to determine the barriers in the implementation of the PPP scheme fo the Tram project. The research variables were obtained from literature review and were divided into 6 groups, namely Social, Legal, Economic, Environmental, Political, and Technology (SLEEPT). The research data was acquired based on four experts' opinion in this area. Relative Important Index (RII), Confidence Interval (CI), and Pareto Diagram were employed to analyse the data. According to Pareto Diagram (81\%), it was found that the economic variable had the two highest indicators, namely "High PPP procurement costs" with an RII value of 0.83 and "Weak access to PPP financing" with value of 0.77. Meanwhile, the legal variable has one indicator with the lowest value, namely the "Lack of Flexibility in Implementation" indicator with an RII value of 0.57.
\end{abstract}

Kerjasama Pemerintah Badan Usaha (KPBU) merupakan salah satu solusi pembiayaan dalam pemenuhan infrastruktur untuk pelayanan publik yang lebih baik. Pesatnya laju pertumbuhan penduduk di Kota Surabaya menjadi tantangan dalam mengembangkan infrastruktur transportasi. Salah satu upaya yang coba dilakukan adalah dengan menghidupkan kembali transportasi masal berbasis rel atau disebut Tram. Tujuan dari penelitian ini adalah untuk mengetahui indikator penghambat dalam pelaksanaan skema KPBU dalam pengadaan Tram. Variabel diperoleh dari studi literatur dan terbagi dalam 6 kelompok yaitu Social, Legal, Economic, Environment, Politic, and Technology (SLEEPT). Data berdasarkan pendapat empat pakar di bidang transportasi. Analisis data menggunakan Relative Important Index (RII), Confidence Interval (CI), dan Diagram Pareto untuk menentukan urutan peringkat dari indikator yang berpengaruh. Dari hasil Diagram Pareto sebesar $81 \%$ ditemukan variabel ekonomi memiliki dua nilai indikator tertinggi yaitu indikator "Tingginya biaya pengadaan KPBU" dengan nilai RII 0,83 dan "Lemahnya akses pembiayaan KPBU" dengan nilai 0,77. Variabel legal memiliki satu indikator dengan nilai terendah yaitu indikator "Kurangnya Flexibilitas dalam implementasi”" dengan nilai RII 0,57.

\section{Pendahuluan}

Predikat sebagai kota terbesar dengan pertumbuhan penduduk yang signifikan menyebabkan Kota Surabaya tidak terlepas dari masalah hambatan mobilitas dan kemacetan lalu-lintas yang dapat memberikan dampak sosial, ekonomi, dan lingkungan. Oleh sebab itu, dari permasalahan kota dan rencana strategis, Pemerintah Kota Surabaya memilih sarana publik berupa angkutan masal Tram sebagai alternatif solusinya. Sebelumnya Tram pernah menjadi sarana yang cukup penting di Kota Surabaya pada tahun 1889 dengan trayek sepanjang $47 \mathrm{~km}$ dan sempat berhenti beroperasi pada tahun 1978. Beberapa waktu belakangan ini Pemerintah Kota Surabaya berupaya mencoba menghidupkan kembali proyek Tram Surabaya dengan rute antara lain dari Joyoboyo - Tugu
Pahlawan - Jembatan Merah dan kembali lagi dengan arah berlawanan, Pemerintah Kota Surabaya merencanakan dalam pelaksanaannya proyek ini akan menggunakan skema Kerjasama Pemerintah Badan Usaha (KPBU).

Fasilitas infrastruktur menjadi salah satu perhatian khusus pemerintah untuk mempercepat penyediaan infrastruktur publik dengan mekanisme KPBU. Hal ini dilakukan untuk berbagi risiko pengadaan layanan infrastruk-tur publik, memastikan kualitas produk dan layanan, serta mengurangi biaya yang dikeluarkan oleh pemerintah [1]. KPBU mendapat perhatian khusus dalam pengembangan dan pembiayaan fasilitas infrastruktur publik, skema ini telah digunakan oleh lebih dari 40 negara [2]. Kerjasama ini dilakukan untuk mempercepat pertumbuhan ekonomi, meningkatkan kesejah- 
teraan masyarakat, dan mewujudkan tersedianya pelayanan publik yang lebih baik. Pada prinsipnya infrastruktur publik untuk pelayanan publik harus memberikan manfaat yang sebesar-besarnya dan meminimalkan dampak negatif yang dapat merugikan masyarakat [3].

Namun ada beberapa kendala yang sering terjadi dalam skema KPBU, seperti kesiapan para pemangku kepentingan untuk mengimplementasikannya di negara berkembang dan kapasitas badan usaha dalam mengelola proyek pemerintah [2] [4]. Dalam konsentrasi biaya, mutu, dan waktu, permasalahan tingginya biaya yang dikeluarkan untuk realisasi proyek KPBU dan waktu pengadaan yang cukup lama, bahkan dalam pelaksanaan proyek KPBU dapat terjadi overkomersialisasi [5] [6].

Ada beberapa kota besar dunia yang telah menerapkan konsep Tram seperti Melbourne (Australia) dan Toronto (Kanada). Di kedua kota tersebut, Tram didesain dengan lintasan campuran, meskipun pada akhirnya Tram menyesuaikan kecepatannya sehingga dapat mengurangi kecelakaan lalu lintas [7].

Namun, upaya menerapkan konsep Tram di Surabaya bukan hal yang mudah. Ada beberapa hal yang membuat rencana ini masih belum bisa dilaksanakan hingga saat ini, diantaranya adalah karena keterbatasan pembiayaan dan masa konstruksi yang diprediksi lebih dari dua tahun. Hal itu tentu menjadi kendala karena masa berlaku Rencana Tata Ruang Wilayah Kota Surabaya terhitung lima tahun sampai dengan akhir tahun 2019. Oleh karena itu tujuan dari penelitian ini adalah untuk melakukan investigasi terhadap faktor penghambat implementasi skema KPBU dalam pengadaan Tram di Surabaya.

\section{Metode}

Studi ini menggunakan metode kuantitatif dengan menganalisis data yang diperoleh dari survei pendahuluan dan utama. Tujuannya untuk mengumpulkan informasi aktual secara detail dan mengidentifikasi permasalahan dalam praktik KPBU. Obyek yang ditinjau adalah proyek transportasi masal berbasis rel di Kota Surabaya.

Pendekatan dengan menggunakan pendapat pakar lebih dipilih karena di samping supaya kualitas data lebih baik juga karena terbatasnya jumlah calon responden karena proyek transportasi masal berbasis rel di Kota Surabaya masih dalam tahap perencanaan.

Pakar merupakan akademisi di bidang ilmu transportasi dan praktisi dari instansi pemerintah yang terlibat dalam ide awal proyek transportasi masal berbasis rel di kota Surabaya. Mengacu dari [8], studi ini melibatkan empat orang pakar pada survei pendahuluan. Sedangkan pada survei utama di- dasarkan pada pendapat tujuh responden seperti yang dilakukan pada studi sebelumnya [9].

Hasil survei diuji menggunakan uji validitas dan reliabilitas serta dianalisis menggunakan Relative Importance Index (RII) untuk mengetahui indikator yang paling signifikan menghambat proyek transportasi masal berbasis rel dengan skema KPBU dan analisis Confidence Interval (CI) untuk mengukur tingkat kepercayaan. Hasil dari Relative Important Index dan Confident Interval disajikan dengan Pareto Diagram.

\subsection{Relative Important Indeks (RII)}

Analisis Relative Important Index (RII) dilakukan setelah hasil uji validitas dan reliabilitas, tujuan dari penggunaan analisis ini adalah untuk mengetahui rangking indikator yang menggambarkan tingkat kepentingan yang menghambat penyelenggaraan transportasi masal berbasis rel di Kota Surabaya. Perhitungan Relative Important Index ditunjukkan pada persamaan 1 dimana tingkat kepentingan diukur dari hasil pengisian kuesioner berdasarkan persepsi dan tingkat kepentingan dari masing-masing responden yang dianalisa tiap indikatornya, kuesioner diisi dengan indeks katagori respon (I) yang memiliki nilai antara 1-5. Nilai tersebut menunjukkan bobot kepentingan indikator (W) sesuai dengan penilaian responden. Penjumlahan dari bobot pada setiap indikator dibagi dengan hasil perkalian bobot tertinggi (A). Bobot tertinggi yaitu 5 dan jumlah responden $(\mathrm{N})$. Hasil pada perhitungan RII tersedia pada Tabel 5.

$$
\mathrm{RII}=\frac{\sum_{i=1}^{5} W}{A \cdot N}
$$

Persamaan 1 diatas memiliki keterangan sebagai berikut [10]:

$$
\begin{aligned}
\mathrm{RII}= & \text { Relative Important Index } \\
I= & \text { indeks katagori respon }(1,2,3,4, \text { dan } 5) \\
W= & \text { bobot yang dihubungkan dengan nilai } \\
& \text { respon ke- } I(1,2,3,4, \text { dan } 5) \\
A= & \text { Bobot tertinggi (5) } \\
N= & \text { Jumlah responden }
\end{aligned}
$$

\subsection{Confidence Interval (CI)}

Analisis Confidence Interval (CI) dilakukan setelah hasil Relative Important Index (RII). CI adalah interval berdasarkan pengamatan sampel dan ada probabilitas yang ditentukan. Interval berisi nilai sebenarnya dari parameter yang tidak diketahui. Persamaan 2 menunjukkan interval kepercayaan dihitung dengan probabilitas $95 \%$ dari nilai sebenarnya. Nilai CI diperoleh dari hasil kuesioner dengan menghitung rata-rata $(\bar{x})$ dari setiap indikator yang dijumlahkan dengan hasil perkalian antara nilai $t$ kritis dengan standart error. Hasil dari perhitungan tersebut adalah nilai CI pada setiap indikator. Hasil peringkat CI dapat diihat pada Tabel 6. 


$$
\mathrm{CI}=\bar{x} \pm \mathrm{t}_{(\mathrm{a} / 2, \mathrm{n}-1) \cdot \frac{s t}{\sqrt{n}}}
$$

Persamaan 2 memiliki keterangan sebagai berikut [11] :

$\bar{x}=$ Rata-rata dari total tiap variabel

st $=$ Standar Deviasi

$\mathrm{n}=$ Jumlah responden

$\mathrm{t}=$ Confidence Coefficient

\subsection{Pareto Diagram}

Prinsip Diagram Pareto menggambarkan hasil analisa RII dan CI. Prinsip ini digunakan untuk mendapatkan variabel dengan rangking dari nilai tertinggi hingga terendah serta kumulatif nilai sampai dengan $80 \%$ dari total nilai. Hal ini dapat disimpulkan bahwa indikator dianggap penting karena memiliki bobot mayoritas dari seluruh indikator yang tersedia dalam permasalahan transportasi masal berbasis rel di Kota Surabaya dengan skema KPBU.

\section{Hasil dan Pembahasan}

Pengumpulan data dilakukan dalam dua tahap survei dengan kuesioner. Variabel dan indikator dalam survei didapatkan dari studi literatur.

Tabel 1 menunjukkan terdapat enam variabel dengan 27 indikator yang tersebar disetiap variabelnya. Enam variabel tersebut yaitu: Social, Legal, Economic, Environment, Politic, Technology (SLEEPT) [12]. Variabel ekonomi terdiri dari tujuh indikator, variabel lingkungan terdiri dari empat indikator, variabel legal terdiri dari tiga indikator, variabel politik terdiri dari dua indikator, variabel sosial terdiri dari lima indikator, variabel teknologi terdiri dari enam indikator.

Pendekatan dalam memperoleh variabel dan indikator mengunakan pendekatan SLEEPT yang dianggap telah menjadi suatu alat ukur yang terverifikasi dalam menyediakan ketajaman analisis dalam suatu lingkungan bisnis, metode tersebut memungkinkan pemangku kepentingan untuk membangun sistem yang lebih efektif dan efisien dalam menganalisa suatu skema KPBU [12].

Tabel 1. Data Variabel dan Indikator Penelitian

\begin{tabular}{cll}
\hline No & \multicolumn{1}{c}{ Indikator Penelitian } & \multicolumn{1}{c}{ Sumber } \\
\hline A & Variabel Ekonomi & \\
1 & Biaya yang di bebankan kepada & {$[5][6][12]$} \\
& $\begin{array}{l}\text { pengguna akhir sangat mahal } \\
2\end{array}$ & {$[13][14][15]$} \\
& $\begin{array}{l}\text { Kesulitan dalam memperoleh } \\
\text { fasilitas kredit dari Bank }\end{array}$ & {$[2][6][12]$} \\
3 & $\begin{array}{l}\text { Kurangnya insentif dari peme- } \\
\text { rintah Lemahnya akses dalam }\end{array}$ & {$[4][12][13]$} \\
& $\begin{array}{l}\text { memperoleh pembiayaan KPBU } \\
4\end{array}$ & $\begin{array}{l}\text { Lemahnya akses dalam mem- } \\
\text { peroleh pembiayaan KPBU }\end{array}$ \\
\hline
\end{tabular}

\begin{tabular}{|c|c|c|}
\hline No & Indikator Penelitian & Sumber \\
\hline 5 & $\begin{array}{l}\text { Tidak ada lembaga yang menye- } \\
\text { diakan pembiayaan jangka } \\
\text { panjang }\end{array}$ & $\begin{array}{l}{[2][6][12]} \\
{[13][15][16]}\end{array}$ \\
\hline 6 & $\begin{array}{l}\text { Prospek pertumbuhan ekonomi } \\
\text { lokal buruk }\end{array}$ & {$[6][12][14]$} \\
\hline 7 & $\begin{array}{l}\text { Tingginya biaya pengadaan } \\
\text { KPBU }\end{array}$ & $\begin{array}{l}{[5][6][12]} \\
{[14][15]}\end{array}$ \\
\hline B & Variabel Lingkungan & \\
\hline 8 & Data kurang transparan & $\begin{array}{l}{[2][4][5][6]} \\
{[12][14]}\end{array}$ \\
\hline 9 & $\begin{array}{l}\text { KPBU memiliki risiko yang } \\
\text { tinggi }\end{array}$ & $\begin{array}{l}{[2][5][6][12]} \\
{[14][17]}\end{array}$ \\
\hline 10 & $\begin{array}{l}\text { KPBU membutuhkan jangka } \\
\text { waktu yang panjang }\end{array}$ & $\begin{array}{l}{[4][5][6][12]} \\
{[13]}\end{array}$ \\
\hline 11 & Pembebasan lahan bermasalah & {$[12][13]$} \\
\hline $\begin{array}{r}\mathbf{C} \\
12\end{array}$ & $\begin{array}{l}\text { Variabel Legal } \\
\text { Ketidakpastian parameter pe- } \\
\text { laksanaan }\end{array}$ & {$[4][6][12]$} \\
\hline 13 & $\begin{array}{l}\text { Kurangnya Flexibilitas dalam } \\
\text { implementasi }\end{array}$ & [6] [17] \\
\hline 14 & $\begin{array}{l}\text { Kurangnya standart desain re- } \\
\text { gulasi }\end{array}$ & $\begin{array}{l}{[4][6][12]} \\
{[13][14][15]}\end{array}$ \\
\hline D & Variabel Politik & \\
\hline 15 & Interfensi kepentingan politik & {$[2][6][12]$} \\
\hline 16 & Lemahnya komitmen politik & $\begin{array}{l}{[2][5][12]} \\
{[13][14][16]}\end{array}$ \\
\hline $\mathbf{E}$ & Variabel Sosial & \\
\hline 17 & $\begin{array}{l}\text { Lemahnya Kolaborasi antar } \\
\text { stakeholder }\end{array}$ & [4] [12] \\
\hline 18 & Adanya Oposisi Publik & {$[12][13]$} \\
\hline 19 & Tidak adaya kepercayaan publik & $\begin{array}{l}{[12][13][15]} \\
{[16][17]}\end{array}$ \\
\hline 20 & Kurangnya kepedulian & {$[2][12][13]$} \\
\hline 21 & $\begin{array}{l}\text { Potensi konflik kepentingan } \\
\text { antar stakeholder }\end{array}$ & $\begin{array}{l}{[2][4][5][6]} \\
{[12][15][18]}\end{array}$ \\
\hline $\mathbf{F}$ & Variabel Teknologi & \\
\hline 22 & $\begin{array}{l}\text { Kurangnya efisiensi me- } \\
\text { manajemen }\end{array}$ & [6] [13] \\
\hline 23 & $\begin{array}{l}\text { Kurangnya kapasitas antar } \\
\text { lembaga }\end{array}$ & {$[12][14][16]$} \\
\hline 24 & $\begin{array}{l}\text { Kurangnya kemampuan ber- } \\
\text { inovasi }\end{array}$ & $\begin{array}{l}{[4][13][15]} \\
{[18]}\end{array}$ \\
\hline 25 & $\begin{array}{l}\text { Pemahaman yang rendah dalam } \\
\text { prinsip-prinsip KPBU }\end{array}$ & $\begin{array}{l}{[4][13][14]} \\
{[15]}\end{array}$ \\
\hline 26 & $\begin{array}{l}\text { Keterbatasan pengetahuan } \\
\text { terhadap strategi }\end{array}$ & {$[12][15]$} \\
\hline 27 & $\begin{array}{l}\text { Kurangnya pengalaman } \\
\text { stakeholder }\end{array}$ & {$[5][12]$} \\
\hline
\end{tabular}


Setelah identifikasi variabel, tahapan selanjutnya adalah melakukan survei pendahuluan yang melibatkan pakar dari bidang transportasi. Tabel 2 menunjukkan karakteristik responden pada survei pendahulun yang terdiri atas empat ahli, di mana dua orang dari kalangan akademisi dengan pengalaman kerja lebih dari 10 tahun serta dua orang dari instansi pemerintah yang terlibat pada proyek transportasi masal berbasis rel dengan pengalaman lebih dari lima tahun.

Tabel 2. Data Responden

\begin{tabular}{cccc}
\hline No & Responden & Pengalaman Kerja & $\begin{array}{c}\text { Tingkat } \\
\text { Pendidikan }\end{array}$ \\
\hline 1 & R1 & $>10$ Tahun & S3 \\
2 & R2 & $>10$ Tahun & S3 \\
3 & R3 & 5-10 Tahun & S1 \\
4 & R4 & 5-10 Tahun & D3 \\
\hline
\end{tabular}

Berdasarkan hasil survei pendahuluan ini juga diperoleh pendapat para ahli terhadap variabel penelitian. Lemahnya hubungan antar stakeholder menjadi salah satu variabel yang penting karena skema KPBU memiliki beberapa tahapan yaitu perencanaan, persiapan, transaksi, dan pembangunan yang disetiap tahapannya terdapat parameter tertentu [4], sehingga perlunya komunikasi yang lebih efektif dan kemauan dalam mewujudkan kepentingan bersama, selain itu skema KPBU masih dianggap sinonim dari privatisasi yang menggadaikan aset negara kepada swasta [12] hal ini mengakibatkan kerenggangan hubungan antar stakeholder.

Variabel penting lainnya yaitu sulitnya memperoleh fasilitas pembiayaan untuk proyek KPBU [2], dalam skema ini untuk memperoleh jaminan pembiayaan proyek harus melalui studi dari Penjamin Infrastruktur Indonesia yang memiliki alokasi biaya dan watu tersendiri. Kesulitan dalam pembiayaan membuat Badan Usaha lebih berhati-hati dalam menjalankan bisnis di Indonesia, kestabilan ekonomi dan politik menjadi hal yang paling signifikan untuk menarik minat investor dalam melakukan pembiayaan pengembangan infrastuktur di Indonesia.

\subsection{Hasil Uji Reliabilitas Validitas}

Uji validitas dilakukan untuk menguji isi pertanyaan dalam kuesioner. Hasil uji dikatakan valid dan dapat digunakan untuk mengukur objek penelitian berdasarkan jawaban dari responden. Dasar pengambilan keputusan adalah dengan memperhatikan angka pada kolom Correlation item-total Correlation. Pada Tabel 3 menunjukkan hasil analisis uji reliabilitas yang dilakukan dengan bantuan program SPSS menggunakan koefisien reliabilitas Cronbach Alpha, yaitu jika diuji dengan metode ini, maka $r$ hitung diwakili oleh nilai $a l$ - pha yang dihasilkan. Jika alpha count lebih besar dari 0,6 dan nilai alpha positif, maka instrumen penilaian dapat disebut reliabel [19]. Hasil reliabel menunjukkan konsistensi dari serangkaian alat ukur yang digunakan, hasil tersebut didapatkan setelah melakukan beberapa kali iterasi dari 27 indikator hingga menjadi 17 indikator yang memenuhi nilai valid dan nilai alpha mencapai 0,972.

Tabel 4 menunjukkan hasil uji validitas menggunakan $\mathrm{r}$ tabel 0,754 dengan responden berjumlah tujuh orang [19], Pengujian menggunakan taraf signifikansi 0,05 . Intrepertasi hasil pengujian sebagai berikut:

1. Jika $r$ hitung $>r$ tabel, maka instrumen pertanyaan berkorelasi signifikan terhadap skor total sehingga dinyatakan valid

2. Jika $r$ hitung $<r$ tabel atau $r$ hitung negatif, maka instrumen pertanyaan tidak berkorelasi signifikan terhadap skor total sehingga dinyatakan tidak valid

Hasil analisa validitas menyisihkan 10 indikator sehingga tersisa 17 indikator. Indikator "Data kurang trans-paran" memiliki nilai validitas tertinggi 0,922 . Hasil ini men-dukung penelitian [14], bahwa akuntabilitas dan transparansi mempengaruhi keterbukaan informasi. Sektor Badan Usaha dianggap menutupi informasi penting tertama pada proses penawaran. Indikator "Kurangnya flexibilitas dalam implementasi" memiliki nilai validitas tertinggi kedua 0,900 . Hasil ini mengarah ke sulitnya untuk mendapatkan persetujuan ketika ada pergantian dalam pekerjaan, menurut [17] kondisi ini membuat pihak penjamin harus lebih hatihati dalam penetapan harga produk KPBU.

Tabel 3. Hasil Cronbach's Alpha

\begin{tabular}{lll}
\hline Cronbach's Alpha & N of Items & 17 \\
& 0,972 & \\
\hline
\end{tabular}

\subsection{Relative Important Index (RII)}

Hasil dari uji validitas dan reliabilitas digunakan sebagai input analisa RII, analisa ini digunakan untuk mendapatkan rangking indikator yang menghambat pelaksanaan KPBU dalam pengadaan transportasi berbasis kereta api di Surabaya. Pada Tabel 5 menunjukkan hasil pemeringkatan tertinggi hingga terendah berdasarkan perhitungan RII pada persamaan 1, nilai tertinggi yang dihasilkan adalah 0,83 dan nilai terendah 0,40 . Perhitungan diperoleh dari hasil pengisian kuesioner yang telah dilakukan uji reliabilitas dan validitas, terdapat 17 indikator yang dianalisa menggunakan RII yaitu penjumlahan hasil kuesioner pada tiap indikator yang dibagi dengan hasil perkalian bobot tertinggi dan jumlah responden. 
Tabel 4. Hasil uji validitas

\begin{tabular}{|c|c|c|c|c|}
\hline Kode & Indikator & Nilai r & $\begin{array}{c}\mathrm{r} \\
\text { tabel }\end{array}$ & Hasil \\
\hline $\mathrm{X} 1$ & $\begin{array}{l}\text { Biaya yang di } \\
\text { bebankan kepada } \\
\text { pengguna akhir } \\
\text { sangat mahal }\end{array}$ & 0,795 & 0,754 & Valid \\
\hline $\mathrm{X} 2$ & $\begin{array}{l}\text { Kesulitan dalam } \\
\text { memperoleh fasi- } \\
\text { litas kredit dari } \\
\text { Bank }\end{array}$ & 0,733 & 0,754 & Valid \\
\hline X3 & $\begin{array}{l}\text { Kurangnya insentif } \\
\text { dari pemerintah }\end{array}$ & 0,705 & 0,754 & $\begin{array}{l}\text { Tidak } \\
\text { Valid }\end{array}$ \\
\hline $\mathrm{X} 4$ & $\begin{array}{l}\text { Lemahnya akses } \\
\text { dalam memperoleh } \\
\text { pembiayaan } \\
\text { KPBU }\end{array}$ & 0,812 & 0,754 & Valid \\
\hline X5 & $\begin{array}{l}\text { Tidak ada lembaga } \\
\text { yang menyediakan } \\
\text { pembiayaan } \\
\text { jangka panjang }\end{array}$ & 0,741 & 0,754 & $\begin{array}{l}\text { Tidak } \\
\text { Valid }\end{array}$ \\
\hline X6 & $\begin{array}{l}\text { Prospek per- } \\
\text { tumbuhan e- } \\
\text { konomi lokal } \\
\text { buruk }\end{array}$ & $-0,222$ & 0,754 & $\begin{array}{l}\text { Tidak } \\
\text { Valid }\end{array}$ \\
\hline $\mathrm{X7}$ & $\begin{array}{l}\text { Tingginya biaya } \\
\text { pengadaan KPBU }\end{array}$ & 0,885 & 0,754 & Valid \\
\hline $\mathrm{X} 8$ & $\begin{array}{l}\text { Data kurang trans- } \\
\text { paran }\end{array}$ & 0,922 & 0,754 & Valid \\
\hline X9 & $\begin{array}{l}\text { KPBU memiliki } \\
\text { risiko yang tinggi }\end{array}$ & 0,842 & 0,754 & Valid \\
\hline $\mathrm{X} 10$ & $\begin{array}{l}\text { KPBU mem- } \\
\text { butuhkan jangka } \\
\text { waktu yang } \\
\text { panjang }\end{array}$ & 0,016 & 0,754 & $\begin{array}{l}\text { Tidak } \\
\text { Valid }\end{array}$ \\
\hline X11 & $\begin{array}{l}\text { Pembebasan lahan } \\
\text { bermasalah }\end{array}$ & $-0,249$ & 0,754 & $\begin{array}{l}\text { Tidak } \\
\text { Valid }\end{array}$ \\
\hline $\mathrm{X} 12$ & $\begin{array}{l}\text { Ketidakpastian } \\
\text { parameter pelak- } \\
\text { sanaan }\end{array}$ & 0,482 & 0,754 & $\begin{array}{l}\text { Tidak } \\
\text { Valid }\end{array}$ \\
\hline $\mathrm{X} 13$ & $\begin{array}{l}\text { Kurangnya Flexi- } \\
\text { bilitas dalam } \\
\text { implementasi }\end{array}$ & 0,900 & 0,754 & Valid \\
\hline $\mathrm{X} 14$ & $\begin{array}{l}\text { Kurangnya stan- } \\
\text { dart desain regu- } \\
\text { lasi }\end{array}$ & 0,119 & 0,754 & $\begin{array}{l}\text { Tidak } \\
\text { Valid }\end{array}$ \\
\hline $\mathrm{X} 15$ & $\begin{array}{l}\text { Interfensi ke- } \\
\text { pentingan politik }\end{array}$ & 0,660 & 0,754 & $\begin{array}{l}\text { Tidak } \\
\text { Valid }\end{array}$ \\
\hline
\end{tabular}

\begin{tabular}{|c|c|c|c|c|}
\hline Kode & Indikator & Nilai $r$ & $\begin{array}{c}\mathrm{r} \\
\text { tabel }\end{array}$ & Hasil \\
\hline $\mathrm{X} 16$ & $\begin{array}{l}\text { Lemahnya ko- } \\
\text { mitmen politik }\end{array}$ & 0,813 & 0,754 & Valid \\
\hline X17 & $\begin{array}{l}\text { Lemahnya Ko- } \\
\text { laborasi antar } \\
\text { stakeholder }\end{array}$ & 0,859 & 0,754 & Valid \\
\hline X18 & $\begin{array}{l}\text { Adanya Oposisi } \\
\text { Publik }\end{array}$ & 0,224 & 0,754 & $\begin{array}{l}\text { Tidak } \\
\text { Valid }\end{array}$ \\
\hline X19 & $\begin{array}{l}\text { Tidak adaya keper- } \\
\text { cayaan publik }\end{array}$ & 0,833 & 0,754 & Valid \\
\hline $\mathrm{X} 20$ & $\begin{array}{l}\text { Kurangnya } \\
\text { kepedulian }\end{array}$ & .c & 0,754 & $\begin{array}{l}\text { Tidak } \\
\text { Valid }\end{array}$ \\
\hline X21 & $\begin{array}{l}\text { Potensi konflik ke- } \\
\text { pentingan antar } \\
\text { stakeholder }\end{array}$ & 0,757 & 0,754 & Valid \\
\hline X22 & $\begin{array}{l}\text { kurangnya efisi- } \\
\text { ensi memanajemen }\end{array}$ & 0,756 & 0,754 & Valid \\
\hline $\mathrm{X} 23$ & $\begin{array}{l}\text { Kurangnya kapa- } \\
\text { sitas antar lembaga }\end{array}$ & 0,770 & 0,754 & Valid \\
\hline X24 & $\begin{array}{l}\text { Kurangnya ke- } \\
\text { mampuan ber- } \\
\text { inovasi }\end{array}$ & 0,899 & 0,754 & Valid \\
\hline $\mathrm{X} 25$ & $\begin{array}{l}\text { Pemahaman yang } \\
\text { rendah dalam } \\
\text { prinsip-prinsip } \\
\text { KPBU }\end{array}$ & 0,844 & 0,754 & Valid \\
\hline $\mathrm{X} 26$ & $\begin{array}{l}\text { Keterbatasan } \\
\text { pengetahuan } \\
\text { terhadap strategi }\end{array}$ & 0,804 & 0,754 & Valid \\
\hline $\mathrm{X} 27$ & $\begin{array}{l}\text { Kurangnya } \\
\text { pengalaman } \\
\text { stakeholder }\end{array}$ & 0,843 & 0,754 & Valid \\
\hline
\end{tabular}

Hasilnya nilai RII yang diperoleh berada pada rentang nilai nol sampai dengan satu [9]. Semakin mendekati nilai satu maka variabel tersebut semakin berpengaruh terhadap hambatan pelaksanaan kegiatan KPBU dalam pengadaan transportasi berbasis rel di Surabaya.

Hasil dari analisa RII diperoleh Tingginya biaya pengadaan KPBU sebagai indikator peringkat pertama dengan nilai RII 0,83. Hal ini dimungkinkan terjadi karena dengan skema KPBU biaya dapat berlipat lebih tinggi dibandingkan dengan skema konvensional. Kemungkinan penyebabnya adalah oleh sektor Badan Usaha menambahkan margin keuntungan yang lebih besar untuk menutupi alokasi risiko yang tidak dapat diterima. Namun dengan seiring berjalannya waktu dan semakin meningkatnya pengalaman dalam pengadaan proyek menggunakan skema KPBU, bukan tidak 
mungkin hal ini akan berkurang [5]. Beberapa aspek yang menyebabkan tingginya biaya KPBU berasal dari ketidakpastian penawaran dan permintaan selama masa kontrak serta suku bunga yang tinggi menyebabkan pihak Badan Usaha tidak cukup percaya diri dalam menyediakan ekuitas untuk pembiayaan jangka panjang [14].

Tabel 5. Hasil Relative Important Index (RII)

\begin{tabular}{|c|c|c|c|}
\hline Kode & Indikator Penelitian & RII & Rank \\
\hline $\mathrm{X} 7$ & $\begin{array}{l}\text { Tingginya biaya pengadaan } \\
\text { KPBU }\end{array}$ & 0,83 & 1 \\
\hline $\mathrm{X} 4$ & $\begin{array}{l}\text { Lemahnya akses dalam } \\
\text { memperoleh pembiayaan KPBU }\end{array}$ & 0,77 & 2 \\
\hline $\mathrm{X} 21$ & $\begin{array}{l}\text { Potensi konflik kepentingan } \\
\text { antar pemangku kepentingan }\end{array}$ & 0,71 & 3 \\
\hline $\mathrm{X} 1$ & $\begin{array}{l}\text { Biaya yang di bebankan kepada } \\
\text { pengguna akhir sangat mahal }\end{array}$ & 0,69 & 4 \\
\hline X9 & $\begin{array}{l}\text { KPBU memiliki risiko yang } \\
\text { tinggi }\end{array}$ & 0,69 & 5 \\
\hline $\mathrm{X} 17$ & $\begin{array}{l}\text { Lemahnya kolaborasi antar pe- } \\
\text { mangku kepentingan }\end{array}$ & 0,69 & 6 \\
\hline $\mathrm{X} 16$ & Lemahnya komitmen politik & 0,66 & 7 \\
\hline $\mathrm{X} 25$ & $\begin{array}{l}\text { Pemahaman yang rendah dalam } \\
\text { prinsip-prinsip KPBU }\end{array}$ & 0,63 & 8 \\
\hline $\mathrm{X} 2$ & $\begin{array}{l}\text { Kesulitan dalam memperoleh } \\
\text { fasilitas kredit dari Bank }\end{array}$ & 0,60 & 9 \\
\hline $\mathrm{X} 19$ & Tidak adaya kepercayaan publik & 0,60 & 10 \\
\hline $\mathrm{X} 22$ & $\begin{array}{l}\text { Kurangnya efisiensi } \\
\text { memanajemen }\end{array}$ & 0,60 & 11 \\
\hline $\mathrm{X} 27$ & $\begin{array}{l}\text { Kurangnya pengalaman stake- } \\
\text { holder }\end{array}$ & 0,60 & 12 \\
\hline $\mathrm{X} 13$ & $\begin{array}{l}\text { Kurangnya Flexibilitas dalam } \\
\text { implementasi }\end{array}$ & 0,57 & 13 \\
\hline $\mathrm{X} 26$ & $\begin{array}{l}\text { Keterbatasan pengetahuan terha- } \\
\text { dap strategi }\end{array}$ & 0,57 & 14 \\
\hline $\mathrm{X} 24$ & $\begin{array}{l}\text { Kurangnya kemampuan ber- } \\
\text { inovasi }\end{array}$ & 0,54 & 15 \\
\hline $\mathrm{X} 23$ & $\begin{array}{l}\text { Kurangnya kapasitas antar lem- } \\
\text { baga }\end{array}$ & 0,51 & 16 \\
\hline $\mathrm{X} 8$ & Data kurang transparan & 0,40 & 17 \\
\hline
\end{tabular}

Peringkat tertinggi kedua yaitu indikator Lemahnya akses dalam memperoleh pembiayaan KPBU dengan nilai RII 0,77. Aspek tersebut diungkapkan pula dalam penelitian [2] [12] [13]. kondisi ini sangat bertentangan dengan konsep awal penyelenggaraan skema KPBU. Skema ini diciptakan untuk menarik partisipasi Badan Usaha dalam penyediaan infrastruktur publik. Suku bunga dan biaya pengadaan yang tinggi membuat Badan Usaha sulit dalam terlibat, model ka- rakteristik proyek infrastruktur yang berisiko tinggi, jangka panjang, dan memiliki margin keuntungan yang terbatas semakin membuat Badan Usaha berfikir ulang untuk terlibat dalam proyek infrastruktur. Perlu adanya pemahaman terhadap pemangku kepentingan dalam melakukan perencanaan anggaran untuk skema KPBU, perlu adanya studi kelayakan oleh lembaga penjaminan infrastruktur untuk mempertimbangkan keterbatasan pembiayaan dari pemerintah. Hasil dari analisa tersebut akan digunakan sebagai penjamin dalam memperoleh pembiayaan.

Peringkat tertinggi ketiga yaitu indikator Potensi konflik kepentingan antar pemangku kepentingan dengan nilai RII 0,71 . Kondisi ini disebabkan karena banyaknya pro-ses dan stakeholder yang terlibat sehingga berpotensi dalam penyalahgunaan wewenang, selain itu terdapat tekanan politik yang berbeda saat pengadaan proyek dengan skema konvensional [18]. Kondisi ini menyebabkan Badan Usaha sangat berhati hati dalam mengambil setiap keputusan yang mengakibatkan pembengkakan biaya ataupun keterlambatan penyelesaian proyek, kehati-hatian tersebut mengakibatkan potensi dalam berinovasi menjadi kurang.

Peringkat tertinggi keempat yaitu indikator biaya yang di bebankan kepada pengguna akhir sangat mahal dengan ni-lai RII 0,69. Kondisi ini berhubungan dengan penentuan tarif yang akan diambil alih oleh Badan Usaha, ketidakpastian siklus ekonomi membuat pengembalian dapat memberatkan masyarakat sebagai pengguna fasilitas umum, berbeda dengan pengadaan secara konvensional dengan pembiayaan pascakontruksi yaitu biaya operasional dan pemeliharaan. Diharapkan ada kebijakan lain yang diterapkan sehingga fasilitas pelayanan publik menjadi terjangkau [5].

Peringkat tertinggi kelima yaitu indikator KPBU memiliki risiko yang tinggi dengan nilai RII 0,69. Kondisi ini sangat melekat pada proyek dengan skema KPBU, dengan risiko yang dinilai tinggi maka skema ini melibatkan banyak pihak untuk dapat bersama dalam menopang risiko tersebut, namun konsep tersebut memiliki beberapa macam penerimaan terhadap sektor publik, pertama yaitu skema KPBU melibatkan banyak pemangku kepentingan dengan asumsi memikul tanggung jawab untuk desain, konstruksi, dan pemeliharaan, serta yang kedua skema KPBU yang melibatkan pemangku kepentingan untuk pengambil keputusan dalam analisis risiko, aspek kontrol dari Badan Usaha dan dukungan pembiayaan yang dibebankan ke masyarakat [6]. Tingginya risiko KPBU membuat perlunya regulasi yang lebih sistematis sehingga tidak menjadi penghambat dalam implementasi KPBU kedepannya.

Peringkat indikator keenam dan seterusnya meliputi lemahnya kolaborasi antar pemangku kepentingan $(\mathrm{RII}=0,69)$; 
lemahnya komitmen politik (RII $=0,66)$; pemahaman yang rendah dalam prinsip-prinsip KPBU (RII=0,63); kesulitan dalam memperoleh fasilitas kredit dari bank $(\mathrm{RII}=0,60)$; tidak adaya kepercayaan publik (RII $=0,60)$; kurangnya efisiensi memanajemen $(\mathrm{RII}=0,60)$; kurangnya pengalaman stakeholder $(\mathrm{RII}=0,60)$; kurangnya flexibilitas dalam implementasi (RII $=0,57)$; keterbatasan pengetahuan terhadap strategi (RII $=0,57)$; kurangnya kemampuan berinovasi (RII$=0,54)$; kurangnya kapasitas antar lembaga $(\mathrm{RII}=0,51)$; dan data kurang transparan $(\mathrm{RII}=0,40)$.

\subsection{Confidence Interval (CI)}

CI adalah nilai interval suatu variabel di mana interval ini memiliki probabilitas tertentu dalam kebenaran suatu nilai, probabilitas spesifik ini disebut interval kepercayaan dan titik akhir interval kepercayaan ini disebut batas kepercayaan [9]. Tabel 6 menunjukkan hasil tes interval kepercayaan yang dilakukan untuk mendukung data penelitian dan memperkuat hasil peringkat yang diperoleh dari uji RII. Nilai CI diperoleh dari rata-rata $(\bar{x})$ pada hasil pengisian satu indikator dijumlahkan dengan hasil perkalian antara nilai $t$ kritis dan nilai standart error seperti terlihat pada persamaan 2. Langkah tersebut dilakukan pada setiap indikator. Hasil dari Nilai CI pada setiap indikator menentukan batas kepercayaan, batas atas diperoleh dari nilai rata-rata dijumlahkan dengan nilai CI dan nilai batas bawah dihasilkan dari nilai rata-rata dikurangi dengan nilai CI. Hasil tersebut menunjukkan nilai batas atas yaitu 4,99 dan nilai batas bawah yaitu 1,26 . Nilai batas atas dan bawah dijumlahkan dan dibagi 3 sesuai dengan peringkat [9] sehingga menghasilkan peringkat satu yaitu nilai rata-rata diantara 4,99-3,75, peringkat dua yaitu nilai rata-rata diantara 3,75-2,50, dan peringkat tiga yaitu nilai rata-rata diantara 2,50-1,26. Hasilnya terdapat dua indikator yang ada di peringkat satu, 14 indikator ada di peringkat dua, dan satu indikator ada di peringkat tiga.

Hasil dari Tabel 6 dapat divisualisasikan pada Gambar 1 yang menujukkan diagram batang sebagai rata-rata setiap indikator dan batas peringkat yang ditandai dengan perbedaan warna, yaitu hijau pada peringkat 1 , kuning pada peringkat 2 , dan merah pada peringkat 3 . Pengelompokan peringkat didasarkan pada tinggi diagram batang yang dihasilkan dari perhitungan RII.

Hasil dari analisa CI diperoleh Tingginya biaya pe-ngadaan KPBU dengan hasil RII 0,83 dan lemahnya akses dalam memperoleh pembiayaan KPBU dengan hasil RII 0,77 adalah indikator yang menempati peringkat tertinggi, hal ini menggambarkan bahwa variabel tersebut memiliki pengaruh yang besar dalam penelitian.
Tabel 6. Hasil Confidence Interval (CI)

\begin{tabular}{|c|c|c|c|c|}
\hline Kode & Indikator Penelitian & $\begin{array}{l}\text { Rata- } \\
\text { rata }\end{array}$ & RII & $\begin{array}{c}\text { Ranking } \\
\text { CI }\end{array}$ \\
\hline $\mathrm{X} 7$ & $\begin{array}{l}\text { Tingginya biaya } \\
\text { pengadaan KPBU }\end{array}$ & 4,14 & 0,83 & 1 \\
\hline $\mathrm{X} 4$ & $\begin{array}{l}\text { Lemahnya akses da- } \\
\text { lam memperoleh } \\
\text { pembiayaan KPBU }\end{array}$ & 3,86 & 0,77 & 1 \\
\hline X21 & $\begin{array}{l}\text { Potensi konflik ke- } \\
\text { pentingan antar pe- } \\
\text { mangku kepentingan }\end{array}$ & 3,57 & 0,71 & 2 \\
\hline $\mathrm{X} 1$ & $\begin{array}{l}\text { Biaya yang di be- } \\
\text { bankan kepada peng- } \\
\text { guna akhir sangat } \\
\text { mahal }\end{array}$ & 3,43 & 0,69 & 2 \\
\hline X9 & $\begin{array}{l}\text { KPBU memiliki risiko } \\
\text { yang tinggi }\end{array}$ & 3,43 & 0,69 & 2 \\
\hline $\mathrm{X} 17$ & $\begin{array}{l}\text { Lemahnya kolaborasi } \\
\text { antar pemangku } \\
\text { kepentingan }\end{array}$ & 3,43 & 0,69 & 2 \\
\hline $\mathrm{X} 16$ & $\begin{array}{l}\text { Lemahnya komitmen } \\
\text { politik }\end{array}$ & 3,29 & 0,66 & 2 \\
\hline $\mathrm{X} 25$ & $\begin{array}{l}\text { Pemahaman yang ren- } \\
\text { dah dalam prinsip- } \\
\text { prinsip KPBU }\end{array}$ & 3,14 & 0,63 & 2 \\
\hline $\mathrm{X} 2$ & $\begin{array}{l}\text { Kesulitan dalam mem- } \\
\text { peroleh fasilitas kredit } \\
\text { dari Bank }\end{array}$ & 3,00 & 0,60 & 2 \\
\hline X19 & $\begin{array}{l}\text { Tidak adaya ke- } \\
\text { percayaan publik }\end{array}$ & 3,00 & 0,60 & 2 \\
\hline $\mathrm{X} 22$ & $\begin{array}{l}\text { Kurangnya efisiensi } \\
\text { memanajemen }\end{array}$ & 3,00 & 0,60 & 2 \\
\hline $\mathrm{X} 27$ & $\begin{array}{l}\text { Kurangnya penga- } \\
\text { laman stakeholder }\end{array}$ & 3,00 & 0,60 & 2 \\
\hline $\mathrm{X} 13$ & $\begin{array}{l}\text { Kurangnya Flexibilitas } \\
\text { dalam implementasi }\end{array}$ & 2,86 & 0,57 & 2 \\
\hline X26 & $\begin{array}{l}\text { Keterbatasan penge- } \\
\text { tahuan terhadap } \\
\text { strategi }\end{array}$ & 2,86 & 0,57 & 2 \\
\hline $\mathrm{X} 24$ & $\begin{array}{l}\text { Kurangnya ke- } \\
\text { mampuan berinovasi }\end{array}$ & 2,71 & 0,54 & 2 \\
\hline $\mathrm{X} 23$ & $\begin{array}{l}\text { Kurangnya kapasitas } \\
\text { antar lembaga }\end{array}$ & 2,57 & 0,51 & 2 \\
\hline $\mathrm{X} 8$ & $\begin{array}{l}\text { Data kurang trans- } \\
\text { paran }\end{array}$ & 2,00 & 0,40 & 3 \\
\hline
\end{tabular}

Kedua indikator tersebut masuk ke dalam pengelompokan variabel ekonomi, dalam 13 in-dikator yang diolah terdapat 4 indikator yang masuk ke dalam variabel ekonomi diantaranya 
tingginya biaya pengadaan KPBU [5], lemahnya akses dalam memperoleh pembiayaan KPBU [2], biaya yang di bebankan kepada pengguna akhir sangat mahal [13], dan kesulitan dalam memperoleh fasilitas kredit dari bank [2].

Kondisi ini membuat variabel ekonomi menjadi variabel yang paling berpengaruh dalam hambatan im-plementasi proyek KPBU. Kondisi ini ditemukan pada pe-nelitian serupa, yaitu dengan adanya hambatan ekonomi se-perti tidak adanya partisipasi Badan Usaha untuk berinvestasi sehingga perlu adanya insentif dari Pemerintah. Dengan keadaan variabel ekonomi yang menjadi penghambat maka diperlukan analisa kelayakan dengan memperhatikan biaya investasi dan transparansi pembiayaan proyek dengan skema KPBU [12].

Hasil peringkat indikator ketiga dalam RII dan seterusnya merupakan peringkat kedua dalam analisa CI, hal ini disebabkan karena nilai RII dari indikator tersebut masih di atas nilai ambang batas bawah peringkat kedua dalam analisa CI.

Variabel selanjutnya yang memiliki indikator dengan kumulatif RII tertinggi dan urutan peringkat terbaik adalah variabel sosial dengan tiga indikator yaitu potensi konflik kepentingan antar pemangku kepentingan [2], lemahnya kolaborasi antar pemangku kepentingan [4], dan tidak adanya kepercayaan publik [16].

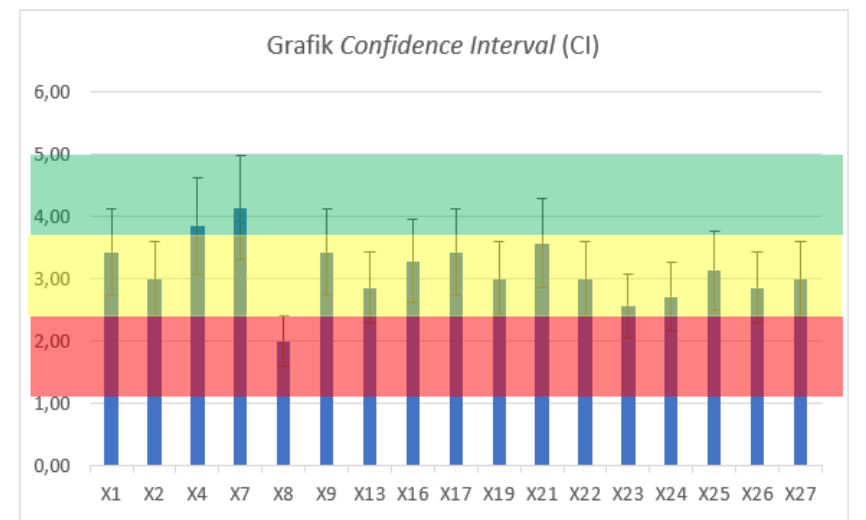

Gambar 1. Diagram Confidence Interval (CI)

Tiga indikator tersebut membuat variabel sosial menjadi variabel yang berpengaruh setelah variabel ekonomi yang dapat menghambat dalam implementasi proyek dengan skema KPBU karena dalam skema tersebut banyak melibatkan pemangku kepentingan yang diharapkan dapat berdiskusi dan bekerjasama dalam membuat inovasi untuk implementasi proyek dengan skema KPBU, namun hal ini dapat membuat penerimaan khalayak umum menjadi ren-dah yang diwujudkan dengan ketidakpercayaan kepada pe- mangku kepentingan yang akan menimbulkan suatu oposisi publik, kondisi ini dapat menghambat keterlibatan investor multinasional karena konflik kepentingan merupakan tantangan serius dalam suatu negara [12]. Oleh karena itu sebelum melakukan impelementasi dalam penyediaan infrastruktur publik menggunakan skema KPBU perlu adanya analisa lebih lanjut terhadap kebutuhan dan tujuan publik.

Variabel selanjutnya yang memiliki nilai RII dan CI terbaik adalah teknologi dengan tiga indikator didalamnya yaitu pemahaman yang rendah dalam prinsip-prinsip KPBU [4], kurangnya efisiensi manajemen [13], dan kurangnya pengalaman stakeholder [5]. Indikator tersebut menggam-barkan ketidaksiapan dan kurangnya kapasitas pemangku kepentingan dalam mengimplementasikan proyek KPBU. Dalam menjalani proyek dengan skema KPBU dibutuhkan tenaga profesional yang memiliki pengalaman dan keterampilan yang lebih untuk mencapai keberhasilan [12].

Variabel selanjutnya adalah lingkungan, politik, dan legal yang memiliki jumlah sama yaitu masing masing satu indikator yang mewakili. Variabel lingkungan yaitu KPBU memiliki risiko yang tinggi [6], dalam hal ini pemangku kepentingan harus menciptakan suatu kondisi lingkungan yang baik sehingga skema KPBU mempunyai daya tarik tersendiri. Variabel selanjutnya adalah politik dengan indikator lemahnya komitmen politik [13], kondisi ini terjadi di lapangan dimana proyek Tram di Kota Surabaya memiliki arah yang berbeda ketika adanya pergantian pimpinan sehingga membuat hal ini sulit diwujudkan. Dalam keadaan yang kurang matang politik di daerah dapat menjadi hambatan dalam implementasi proyek dengan skema KPBU [12]. Variabel terakhir adalah legal dengan satu indikator yaitu kurangnya fleksibilitas dalam implementasi [17], dalam hal ini kerangka hukum dan peraturan yang tidak tumpeng tindih dan perencanaan yang satu tujuan antara pemerintah pusat dan pemerintah daerah menjadi kunci sukses dalam implementasi proyek Tram di Kota Surabaya.

\subsection{Pareto Diagram}

Penelitian ini mencoba menerapkan teori Pareto, dengan menghadirkan $80 \%$ penilaian yang dihasilkan dari nilai Relative Important Index (RII). Pada Tabel 7 menjelaskan bahwa dari enam variabel yang terdapat 27 indikator didalamnya, tersisa 13 indikator yang mencapai nilai RII $81 \%$. Kondisi ini menunjukkan bahwa indikator tersebut masih berpotensi memiliki tingkat kepentingan dan merupakan indikator dengan tingkat mayoritas yang me-nyebabkan masalah pada skema KPBU dalam proyek transportasi masal berbasis rel di Surabaya. 
Tabel 7. Hasil kumulatif RII

\begin{tabular}{|c|c|c|c|}
\hline Kode & Indikator Penelitian & RII & $\begin{array}{c}\text { Kum } \\
(\%)\end{array}$ \\
\hline $\mathrm{X} 7$ & $\begin{array}{l}\text { Tingginya biaya pengadaan } \\
\text { KPBU }\end{array}$ & 0,83 & $8 \%$ \\
\hline $\mathrm{X} 4$ & $\begin{array}{l}\text { Lemahnya akses dalam mem- } \\
\text { peroleh pembiayaan KPBU }\end{array}$ & 0,77 & $15 \%$ \\
\hline $\mathrm{X} 21$ & $\begin{array}{l}\text { Potensi konflik kepentingan an- } \\
\text { tar pemangku kepentingan }\end{array}$ & 0,71 & $22 \%$ \\
\hline $\mathrm{X} 1$ & $\begin{array}{l}\text { Biaya yang di bebankan kepada } \\
\text { pengguna akhir sangat mahal }\end{array}$ & 0,69 & $28 \%$ \\
\hline $\mathrm{X} 9$ & $\begin{array}{l}\text { KPBU memiliki risiko yang } \\
\text { tinggi }\end{array}$ & 0,69 & $35 \%$ \\
\hline $\mathrm{X} 17$ & $\begin{array}{l}\text { Lemahnya kolaborasi antar } \\
\text { pemangku kepentingan }\end{array}$ & 0,69 & $41 \%$ \\
\hline $\mathrm{X} 16$ & Lemahnya komitmen politik & 0,66 & $47 \%$ \\
\hline $\mathrm{X} 25$ & $\begin{array}{l}\text { Pemahaman yang rendah dalam } \\
\text { prinsip-prinsip KPBU }\end{array}$ & 0,63 & $53 \%$ \\
\hline $\mathrm{X} 2$ & $\begin{array}{l}\text { Kesulitan dalam memperoleh } \\
\text { fasilitas kredit dari Bank }\end{array}$ & 0,60 & $59 \%$ \\
\hline X19 & Tidak adaya kepercayaan publik & 0,60 & $64 \%$ \\
\hline $\mathrm{X} 22$ & $\begin{array}{l}\text { Kurangnya efisiensi me- } \\
\text { manajemen }\end{array}$ & 0,60 & $70 \%$ \\
\hline $\mathrm{X} 27$ & $\begin{array}{l}\text { Kurangnya pengalaman stake- } \\
\text { holder }\end{array}$ & 0,60 & $76 \%$ \\
\hline $\mathrm{X} 13$ & $\begin{array}{l}\text { Kurangnya Flexibilitas dalam } \\
\text { implementasi }\end{array}$ & 0,57 & $81 \%$ \\
\hline
\end{tabular}

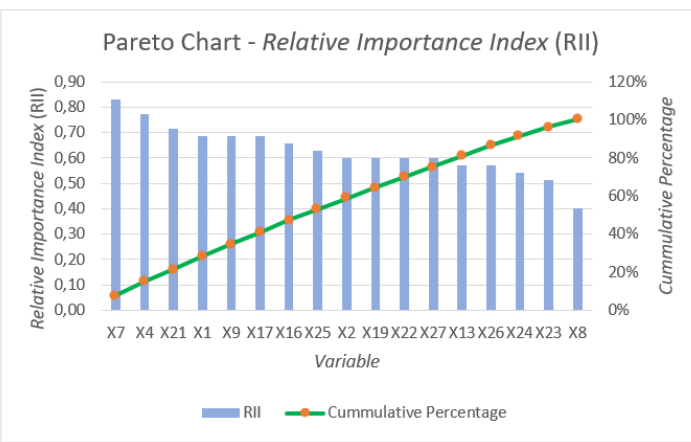

Gambar 2. Diagram Pareto

Pada Gambar 2 menunjukkan hasil RII yang disedikan dari diagram batang pada tiap indikator yang diurutkan dari tertinggi hingga terendah, semikin tinggi nilai RII menunjukkan semakin tinggi tingkat kepentingan indikator, serta diagram garis menunjukkan kumulatif dari nilai RII. Hasil kumulatif RII dari 6 variabel penelitian dapat terlihat dari Tabel 7 hasil pareto dengan nilai 81\%, hasil kumulatif dari indikator variabel ekonomi menunjukkan nilai $27 \%$, selanjutnya disusul oleh variabel sosial dengan nilai 19\%, di- peringkat ketiga terdapat variabel teknologi dengan $17 \%$, selanjutnya variabel lingkungan dan politik memiliki nilai yang sama yaitu $6 \%$, serta variabel legal memiliki nilai 5\%. Nilai tersebut menunjukkan bahwa indikator di dalam variabel merupakan indikator yang dianggap penting karena memiliki bobot mayoritas diantara bobot lainnya.

\section{Simpulan}

Dengan latar belakang penelitian dan literatur yang dilakukan, terdapat 13 indikator yang menghambat implementasi pengadaan transportasi masal berbasis rel di Surabaya dengan skema KPBU. Analisis menggunakan Relative Important Index (RII) dan Confidence Interval (CI). Variabel yang memiliki nilai tertinggi yaitu variabel ekonomi dengan indikator tingginya biaya pengadaan KPBU dan lemahnya akses pembiayaan KPBU, keduanya memiliki nilai RII 0,83 dan 0,77 menjadi yang tertinggi diantara indikator lainnya, nilai RII terendah yaitu indikator data kurang tansparan dengan nilai 0,40 .

Permasalahan ekonomi bersumber dari beban investasi yang tinggi dan teknologi yang digunakan tidak dapat dikembalikan sepenuhnya oleh tarif layanan infrastruktur. Perlu adanya bantuan dana dari pemerintah yang diberikan kepada proyek infrastruktur dengan skema KPBU untuk mendukung kelayakan proyek.

Dari hasil penelitian, total ada empat indikator yang termasuk dalam variabel ekonomi. Variabel kedua yang tertinggi yaitu sosial dengan tiga variabel, selanjutnya secara berurutan yaitu variabel teknologi dengan tiga variabel serta variabel lingkungan, politik, dan legal dengan masing-masing satu indikator. Hasil Diagram Pareto menunjukkan $81 \%$ dari nilai kumulatif analisa RII pada indikator ke-13.

\section{Daftar Pustaka}

[1] J.-F. Yuan, S. Mirosław J, Q. Li and J. Shan, "The Driving Factors Of China's Public-Private Partnership Projects In Metropolitian Transportation Systems: Public Sector's Viewpoint," Journal of Civil Engineering and Management, vol. 16, no. 1, pp. 518, 2010.

[2] Babatunde, S. Perera, L. Zhou and C. Udeaja, "Barriers to public private partnership projects in developing countries: A case of Nigeria," Engineering, Construction and Architectural Management, vol. 22, no. 6, pp. 669 - 691, 2015.

[3] M. A. Rohman and I. P. A. Wiguna, "Evaluation of road design performance in delivering community project social benefits in Indonesian PPP," 
International Journal of Construction Management, 2019.

[4] N. A. Khiyon and S. F. Mohamed, "Barriers and Drivers of Whole Life Cycle Costing of Sustainable Facility Management for PPP/PFI Projects in Malaysia," Chemical Engineering Transactions, vol. 63, pp. 721-726, 2018.

[5] B. Li, A. Akintoye, P. J. Edwards and C. Hardcastle, "Perceptions of positive and negative factors influencing the attractiveness of PPP/PFI procurement for construction projects in the UK: Findings from a questionnaire survey," Engineering, Construction and Architectural Management, vol. 12, no. 2, pp. 125 148, 2005.

[6] C. Chen and H. Doloi, "BOT aplication in China : Driving and impeding factors," International Journal of Project Management, vol. 26, pp. 388-398, 2008.

[7] G. Currie and A. Shalaby, "Seccess and Chalenges in Modernizing Streetcar System Experience in Melborne, Australia and Toronto, Canada," Journal of the Transportation Research Board, pp. 31-39, 2007.

[8] F. Kristiawan and M. A. Rohman, "Penilaian Kriteria Sukses Proyek Kerjasama Pemerintah dengan Badan Usaha (KPBU) pada Proyek Jalan Tol di Indonesia," Repository ITS, Surabaya, 2021.

[9] Pujiarman, T. J. W. Adi and I. Warmadewanthi, "Faktor-faktor Keberhasilan Pengelolaan Insfrastruktur Air Limbah berbasis Masyarakat Kabupaten Soppeng," Repository ITS, Surabaya, 2016.

[10] M. Gündüz, Y. Nielsen and M. Özdemir, "Quantification of Delay Factors Using the Relative Importance Index Method for Construction Projects in Turkey," Journal of Management in Engineering, vol. 29, no. 2, pp. 133-139, 2013.

[11] W. Hernandez, A. Mendez, R. Zalakeviciute and A. M. D. Marquez, "Robust Confidence Intervals for PM2.5 Concentration Measurements in the Ecuadorian Park La Carolina," Sensors, vol. 20, p. 645, 2020 .
[12] M. K. Al-Hanawi, "Barriers to the implementation of public-private partnerships in the healthcare sector in the Kingdom of Saudi Arabia," PLOS ONE, vol. 15, no. 6,2020 .

[13] K. Weththasinghe, G. Brewer and T. Gajendran, "Barriers in Proper Implementation of Public Private Partnership (PPP) in Sri Lanka," in 40 th AUBEA 2016 Radical Innovation in the Built Environment, Sri Lanka, 2016.

[14] R. Janssen, R. d. Graaf, M. Smit and H. Voordijk, "Why local governments rarely use PPPs in their road development projects: Understanding the barriers," International Journal of Managing Projects in Business, vol. 9, no. 1, pp. 33 - 52, 2016.

[15] D. Kamugurnya, "Health system's barriers hindering implementation of public-private partnership at the district level: a case study of partnership for improved reproductive and child health services provision in Tanzania," BMC Health Services Research, p. 16:596, 2016.

[16] A. Mahalingam, "PPP Experiences in Indian Cities Barriers, Enablers, and the way forward," Journal of Construction Engineering and Management, pp. 136 : 419-429, 2010

[17] S. O. Babatunde and S. Perera, "Barriers to bond financing for public-private partnership infrastructure projects in emerging markets: a case of Nigeria," Journal of Financial Management of Property and Construction, vol. 22, no. 1, 2017.

[18] L. Gunnigan and D. Eaton, "Barriers to Innovation in Public-Private Partnership (PPP)," in Proceedings of COBRA - The construction and building research conference of the Royal Institution of Chartered Surveyors, Technological University of Dublin, 2008.

[19] H. Oktianatasari, "Audit Tata Kelola Teknologi Informasi pada PT Pelabuhan Indonesia III (Persero) dengan kerangka kerja Cobit 5," Institut Teknologi Sepuluh Nopember, Surabaya, 2017. 